Yol.2 2Nn. I لanuari 2019

ISSN 2614-2775

e-ISSN 2621-8143

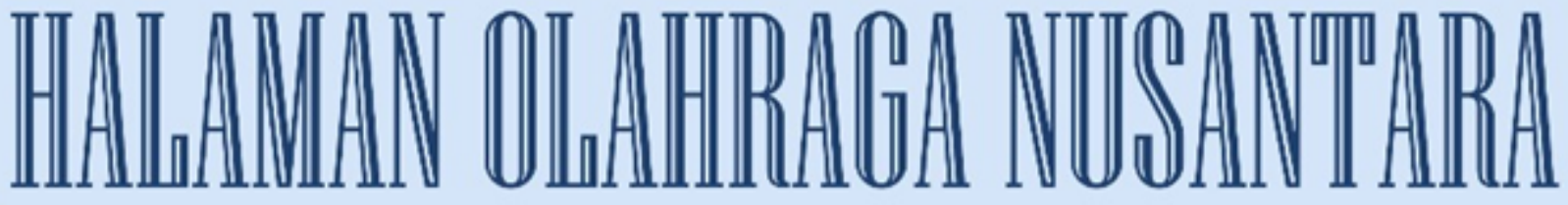

Surnal @lmu Xeolahragaan

Diterbitkan Oleh:

Program Studi Pendidikan Olahraga

Fakultas Keguruan dan Ilmu Pendidikan

Universitas PGRI Palembang

Jurnal

Volume Nomor Halaman Palembang ISSN/e-ISSN

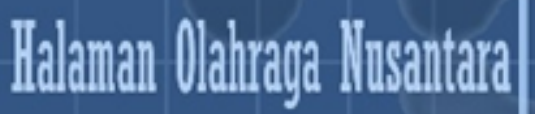

\begin{tabular}{l|l|l|l}
2 & 1 & $1-96$ & 2019
\end{tabular}




\section{Halaman Olahraga Nusantara}

Jurnal Ilmu Keolahragaan

Volume 2, Nomor 1, Januari 2019

Pelindung/Penasehat

Dr. H. Bukman Lian, M. M., M. Si.

Penanggung Jawab

Dr. Dessy Wardiah, M. Pd.

Ketua Dewan Redaksi

Farizal Imansyah, M. Pd.

Wakil Ketua Dewan Redaksi

Ilham Arvan Junaidi, M. Pd.

Sekretaris

Bayu Iswana, M. Pd.

Penyunting Pelaksana

Rafel Orlando, M. Pd.

Ardo Okilanda, M. Pd.

Daryono, M. Pd.

\section{Mitra Bestari}

Prof. Dr. A. Sofyan Hanif, M. Pd (Universitas Negeri Jakarta)

Dr. Sukirno (Universitas Sriwijaya)

Dr. Ronni Yenes, M. Pd (Universitas Negeri Padang)

Dr. Benny, M. Pd. (Universitas Negeri Makasar)

Dr. Putri Cicilia Kristina, M. Pd (Universitas PGRI Palembang)

\section{Tata Usaha}

M. Taheri Akbar, M. Pd.

Widya Handayani, S. Pd., M. Si.

Setting:

Dede Dwiansyah Putra, M. Pd.

Alamat Redaksi:

Prodi Pendidkan Olahraga Fakultas Keguruan Ilmu dan Pendidikan Universitas PGRI Palembang

Jl. Jendral A. Yani Lorong Gotong Royong 9/10 Ulu Palembang

Telp. 0711-510043, Fax. 0711-514782

e-mail jurnal: jurnalhonupgripalembang@gmail.com

e-mail : ardo.oku@univpgri-palembang.ac.id

website: univpgri-palembang.ac.id 
Halaman Olahraga Nusantara (Jurnal Ilmu Keolahragaan)

P-ISSN 2614-2775

Volume 2, No. 1, Januari 2019

E-ISSN 2621-8143

\section{DAFTAR ISI}

Hasil Penelitian

Halaman

Pengaruh Metode Rangkaian Bermain Terhadap Keterampilan Dasar Olahraga Panahan Siswa Ektrakulikuler Sit (Sekolah Islam Terpadu) Auladi Palembang

- Arisman

Penerapan Metode Bermain Dalam Meningkatkan Hasil Belajar Guling Depan (Forward Roll)

- Ruslan, M. Samsul Huda

Survei Tingkat Kesegaran Jasmani pada Peserta Ekstrakulikuler Sepakbola Di Sma Negeri 2 Oku

- Daryono

Kontribusi Daya Ledak Tungkai dan Keseimbangan Terhadap Kemampuan Lompat Jauh Murid Sd Negeri 139 Sinjai

- Adam Mappaompo

Survei Tingkat Kebugaran Jasmani Mahasiswa Pendidikan Olahraga Angkatan 2017 Stkip Pgri Bangkalan

- Heni Yuli Handayani .

Profil Delayed Onset Muscle Soreness (Doms) pada Mahasiswa Fik Unp Setelah Latihan Fisik

- Heru Syarli Lesmana

Perbedaan Pengaruh Latihan Menggunakan Karet dengan Menggunakan Dumbbell $1 \mathrm{Kg}$ Terhadap Kecepatan Pukulan Oi Tsuki

Chudan pada Atlet Karate Putra Perguruan Wadokai Dojo Sma Negeri 11 Medan Tahun 2017

- Pangondian Hotliber Purba $60-71$

Tinjauan Kondisi Fisik Atlet Sepakbola Kabupaten Kerinci Dalam

Rangka Persiapan Mengikuti Porprov Xxii Bungo Tebo 2018

- Palmizal, Wawan Junresti Daya, dan Sri Murniati

Aktivitas Jasmani dan Persepsi Gerak Anak Usia Dini

- Dian Pujianto 
Peningkatan Keterampilan Bermain Bolabasket Mahasiswa Melalui Latihan Aktifitas Maze Perkuliahan Permainan Bolabasket

- Ilham Arvan Junaidi dan Rury Rizhardy $88-96$ 


\title{
TINJAUAN KONDISI FISIK ATLET SEPAKBOLA KABUPATEN KERINCI DALAM RANGKA PERSIAPAN MENGIKUTI PORPROV XXII BUNGO TEBO 2018
}

\author{
Oleh: Palmizal, Wawan Junresti Daya, dan Sri Murniati \\ (Dosen Universitas Jambi)
}

\begin{abstract}
Abstrak
Penelitian ini bertujuan untuk melihat bagaimana keadaan kondisi fisik atlet sepakbola Kabupaten Kerinci yang akan berlaga pada ajang Pekan Olahraga Provinsi (Porprov) XXII Bungo Tebo. Sedangkan manfaat penelitian ini adalah setelah di ketahui profil kondisi fisik atlet tersebut, maka setelah itu dapat diberikan masukan dan saran kepada tim pelatih sebagai bahan pertimbangan persiapan tim. Penelitian ini merupakan penelitian deskriptif, yaitu suatu penelitian yang bertujuan untuk mengetahui dan mendapatkan gambaran atau kenyataan yang sesungguhnya dari keadaan objek yang diteliti tanpa ada suatu maksud untuk mengambil kesimpulan-kesimpulan yang berlaku secara umum. Metode yang digunakan adalah survei dengan teknik pengumpulan data menggunakan tes dan pengukuran. Penelitian ini bertujuan untuk mengetahui profil kondisi fisik pemain sepakbola Kabupaten Kerinci. Hasil akhir dari kegiatan penelitian ini adalah terlihatnya profil kondisi fisik atlet sepakbola Kabupaten Kerinci yang akan berlaga pada porprov XXII. Komponen kondisi fisik yang akan di tes meliputi, Daya Ledak, Kecepatan, Daya Tahan (VO2max), dan Kelincahan. Tes dilakukan kepada 26 orang atlet sepakbola kabupaten kerinci yang akan mengikuti porprov 2018. tes kondisi fisik yang dilaksanakan adalah tes bleep test, tes lari 50m, test vertical jump, dan tes shuttle run. Hasil Penelitian menunjukkan bahwa kondisi fisik atlet sepakbola kerinci adalah sedang, 10 orang atlet dalam kategori sedang atau 38.46\%, 3 orang atlet pada kategori baik sekali atau 11.53\%, 5 orang atlet dalam kategori baik atau 19.23\%, 7 orang atlet dalam kategori kurang atau 26.92\%, dan 1 orang atlet pada kategori kurang sekali atau 3.84\%. Dari hasil penelitian dapat disimpulkan bahwa kondisi fisik atlet sepakbola kabupaten kerinci yang akan mengikuti porprov 2018 berada pada kategori sedang.
\end{abstract}

Kata Kunci: Kondisi Fisik, Sepakbola, Kerinci

\section{REVIEW OF PHYSICAL CONDITIONS OF THE KERINCI DISTRICT FOOTBALL ATLET IN PREPARATION FOR THE XXII BUNGO TEBO PORPROV 2018}

\begin{abstract}
This study aims to see how the physical condition of football athletes in Kerinci will compete in the Bungo Tebo XXII Porprov. While the benefits of this research are that after the profile of the athlete's physical condition is known, then input and suggestions can be given to the coach team as a consideration for
\end{abstract}


team preparation. This research is a descriptive research, which is a study that aims to find out and get a real picture or reality of the state of the object under study without any intention to draw conclusions that apply in general. The method used is a survey with data collection techniques using tests and measurements. This study aims to determine the profile of the physical conditions of Kerinci Regency football players. The final result of this research activity is the profile of the physical condition of the football athletes in Kerinci Regency who will compete in Porprov XXII. Components of the physical conditions to be tested include, Explosive Power, Speed, Durability (VO2max), and Agility. The test was carried out on 26 people from the Kerinci district soccer athlete who will take part in porprov 2018. The physical condition tests carried out were the bleep test, $50 \mathrm{~m}$ run test, vertical jump test, and shuttle run test. The results showed that the physical condition of football athletes in Kerinci was moderate, 10 athletes in the medium category or $38.46 \%$, 3 athletes in the excellent category or $11.53 \%, 5$ athletes in the good category or 19.23\%, 7 athletes in the poor category or $26.92 \%$, and 1 athlete in the category less or $3.84 \%$. From the results of the study it can be concluded that the physical condition of the Kerinci district athletes who will participate in porprov 2018 are in the moderate category.

Keyword: Physical Condition, Football, Kerinci

\section{A. PENDAHULUAN}

Olahraga merupakan salah satu wadah untuk meningkatkan sumber daya manusia. Olahraga yang teratur dan kontinyu dapat meningkatkan kualitas fisik dan mental seseorang. Untuk itu pembinaan dibidang olahraga perlu diperhatikan, terutama peningkatan kondisi fisik dan mental dalam upaya pembentukan manusia Indonesia yang mempunyai kepribadian, berdisplin tinggi serta memiliki sikap sportif. Disamping meningkatkan kualitas fisik dan mental, olahraga juga mengangkat citra bangsa dan kebangsaan nasional melalui pencapaian prestasi setinggi- tingginya.

Sepakbola menjadi suatu olahraga yang begitu populer di berbagai belahan dunia termasuk juga di Indonesia dan sudah tidak asing lagi terdengar di telinga kita. Semua orang suka dengan sepakbola baik itu orang tua, dewasa hingga anakanak, tidak hanya kaum laki-laki saja yang gemar dengan olahraga ini bahkan kaum perempuan pun suka dengan sepakbola. Menjamurnya permainan sepakbola telah merambah ke semua daerah di tanah air, tidak hanya di daerah perkotaan tetapi di daerah pedesaan juga sering memainkan olahraga sepakbola. 
Salah satu unsur atau faktor penting untuk meraih suatu prestasi dalam Sepakbola, disamping penguasaan teknik, taktik, dan kemampuan mental adalah kondisi fisik. Seberapa besar penting dan pengaruhnya terhadap pencapaian suatu pencapaian suatu prestasi olahraga sangat tergantung kepada kebutuhan atau tuntunan setiap cabang olahraga. Di sisi lainnya banyak pula cabang olahraga yang membutuhkan kondisi fisik. Oleh karena itulah untuk mengetahui komponen kondisi fisik yang dibutuhkan dan seberapa besar tingkat kondisi fisik yang diperlukan serta bagaimana meningkatkanya melalui latihan, perlu adanya pemahaman yang menyeluruh terhadap kondisi fisik.

Menurut Mochamad Sajoto (1999:8) kondisi fisik adalah satu kesatuan utuh dari komponen-komponen yang tidak dapat dipisahkan begitu saja, baik peningkatan maupun pemeliharaanya. Artinya bahwa di dalam usaha peningkatan kondisi fisik maka seluruh komponen tersebut harus dikembangkan, walaupun disana sini dilakukan dengan sistem prioritas sesuai keadaan atau status tiap komponen.

Komponen- komponen kondisi fisik menurut Mochamad Sajoto (1999: 8-10) yaitu (1) kekuatan (strength), (2) daya tahan (endurance), (3) daya otot (muscular power), (4) kecepatan (speed), (5) daya lentur (flexibility), (6) kelincahan (agility), (7) koordinasi (coordination), (8) keseimbangan (balance), (9) ketepatan (accuracy) dan, (10) reaksi (reaction). Lebih lanjut dijelaskan oleh Albertus Fenanlampir dan Muhammad Muhyi Faruq (2014: 234) bahwa komponen dan klasifikasi kemampuan fisik cabang olahraga sepakbola (putra) yaitu (1) kekuatan, (2) daya tahan otot, (3) speed, (4) kelincahan, (5) fleksibilitas, (6) power dan, (7) daya tahan jantung paru.

Kabupaten Kerinci, sebagai salah satu peserta yang akan ikut pada gelaran porprov XXII Bungo Tebo, saat ini sedang melakukan persiapan untuk mengikuti cabang olahraga sepakbola pada gelaran porpov tersebut, persiapan yang dilakukan secara keseluruhan meliputi, teknik, fisik, taktik dan mental. sebagai salah satu kabupaten yang sangat kental tradisi juara pada cabang sepakbola, saat ini Kabupaten kerinci sangat minin prestasi. terakhir kali 
kabupaten kerinci meraih juara pada Proprov 2008, artinya sudah sepuluh tahun kabupaten kerinci tidak bisa menjadi juara pada gelaran bergengsi yang itu pekan olahraga provinsi.

Menurut Mochamad Sajoto (1999: 8), kondisi fisik adalah satu kesatuan utuh dari komponen-komponen yang tidak dapat dipisahkan begitu saja, baik peningkatan maupun pemeliharaan. Artinya bahwa di dalam usaha peningkatan kondisi fisik maka seluruh komponen tersebut harus berkembang. Menurut Mochamad Sajoto (1999: 8), kondisi fisik adalah satu kesatuan utuh dari komponen-komponen yang tidak dapat dipisahkan begitu saja, baik peningkatan maupun pemeliharaannya.

Komponen dan klasifikasi kemampuan cabang olahraga sepakbola putra menurut Albertus Fenanlampir dan Muhammad Muhyi Faruq (2014: 234) sebagai berikut:

a. Kekuatan

Kekuatan adalah tenaga kontraksi otot yang dicapai dalam sekali usaha maksimal. Usaha maksimal dilakukan oleh otot atau sekelompok otot untuk mengatasi suatu tahanan. Kekuatan otot yang diperlukan dalam sepakbola terdiri atas:

1) Otot lengan dan bahu

2) Otot punggung

3) Otot tungkai

b. Daya tahan otot

Daya tahan otot adalah kemampuan seluruh organisme tubuh untuk mengatasi lelah pada waktu melakukan aktivitas yang menuntut kekuatan dalam waktu yang lama. Daya tahan otot yang diperlukan dalam sepakbola terdiri atas:

1) otot perut

2) otot tangan dan bahu

3) otot tungkai 
c. Speed

Speed atau kecepatan adalah kemampuan bergerak dengan kemungkinan kecepatan tercepat. Ditinjau dari sistem gerak, kecepatan adalah kemampuan dasar mobilitas sistem saraf pusat dan perangkat otot untuk menampilkan gerakan-gerakan pada kecepatan tertentu.

d. Kelincahan

Kelincahan adalah kemampuan untuk mengubah arah dan posisi tubuh atau bagian-bagiannya secara cepat dan tepat.

e. Fleksibilitas

Fleksibilitas atau kelentukan merupakan kemampuan menggerakan tubuh atau bagian-bagiannya seluas mungkin tanpa terjadi ketegangan sendi dan cedera otot.

f. Power

Power atau daya ledak disebut juga kekuatan eksplosif. Power menyangkut kekuatan dan kecepatan kontraksi otot yang dinamis dan eksplosif serta melibatkan pengeluaran otot yang maksimal dalam waktu yang secepatcepatnya. Power yang diperlukan dalam sepakbola adalah otot tungkai.

g. Daya tahan jatung paru

Daya tahan jantung dan paru adalah kapasitas sistem sirkulasi (jantung, pembuluh darah, dan darah) dan sistem respirasi (paru) untuk mendistribusikan oksigen ke otot yang sedang bekerja dan mengangkut limbah dari otot-otot tersebut.

Menurut Muhajir (2004: 22) "Sepakbola adalah suatu permainan yang dilakukan dengan jalan menyepak, yang mempunyai tujuan untuk memasukkan bola ke gawang lawan dengan mempertahankan gawang tersebut agar tidak kemasukan bola. Didalam permainan sepakbola, setiap pemain diperbolehkan menggunakan seluruh anggota badan kecuali tangan, hanya penjaga gawang diperbolehkan memainkan bola dengan kaki dan tangan. 


\section{B. METODOLOGI DAN PEMBAHASAN}

Penelitian ini merupakan penelitian deskriptif, Metode yang digunakan adalah survei dengan teknik pengumpulan data menggunakan tes dan pengukuran. Penelitian ini bertujuan untuk mengetahui profil kondisi fisik pemain sepakbola atlet sepakbola Kabupaten Kerinci. Subyek penelitian ini adalah atlet sepakbola kabupaten kerinci yang sedang menjalani persiapan untuk mengikuti pecan olahraga Provinsi Jambi ke XXII di Kabupaten Bungo Tebo tahun 2018 yang berjumlah 23 orang. Instrument yang digunakan dalam penelitian ini untuk pengambilan data yang berkaitan dengan profil kondisi fisik atlet sepakbola Kabupaten Kerinci yaitu : dengan 4 (empat) item tes sebagai berikut :

1. Kecepatan

2. Kelincahan

3. Daya ledak otot tungkai

4. Daya tahan jantung paru (Vo2max)

Setelah diketahui profil kondisi atlet sepakbola Kabupaten Kerinci, yang termasuk kategori baik sekali, baik, sedang, kurang, kurang sekali, maka akan dapat ditentukan berapa besar persentase.

Dari penelitian ini dapat dideskripsikan tinjauan kondisi fisik atlet sepakbola kerinci setelah di T-SCORE dengan rata-rata 200, nilai tengah sebesar 197,62, nilai simpangan baku sebesar 20,59. sedangkan skor tertinggi adalah 247,84 dan skor terendah adalah 168,78. Kemudian dapat di ketahui bahwa tinjauan kondisi fisik atlet sepakbola kerinci adalah sedang. dengan melihat pertimbangan frekuensi terbanyak berada pada kategori sedang dengan 10 orang atlet atau dengan persentasi $38.46 \%$. Sedangkan atlet pada kategori baik sekali 3 orang atau $11.53 \%$, atlet pada kategori baik sebanyak 5 orang atau 19,23\%, atlet pada kategori kurang 7 orang atau 26,92\% dan atlet pada kategori kurang sekali sebanyak 1 orang atau $3.84 \%$. 


\section{KESIMPULAN}

Berdasarkan hasil penelitian dan pembahasan pada bab sebelumnya, maka dapat di simpulkan bahwa kondisi fisik atlet sepakbola kabupaten kerinci berada pada kategori sedang.

\section{DAFTAR PUSTAKA}

Albertus Fenanlampir dan Muhammad Muhyi Faruq. 2014. Tes dan Pengukuran dalam Olahraga. Yogyakarta: CV. Andi Offset.

Mochamad Sajoto. 1988. Pembinaan Kondisi Fisik dalam Olahraga. Jakarta: DEPDIKBUD.

1999. Peningkatan \& Pembinaan Kekuatan Kondisi Fisik Olahraga. Jakarta: Dahara Prize.

Muhajir. (2004). Pendidikan Jasmani Teori dan Praktik. Jakarta: Erlangga. 


\section{GAYA SELINGKUNG}

1. Jurnal Halaman Olahraga Nusantara menerbitkan karya ilmiah dan hasil penelitian dalam seluruh kajian ilmu keolahragaan, baik pendidikan, kepelatihan, dan lainya dalam pengembangan teori dan konsep yang belum pernah dipublikasikan. Jurnal ini memuat (1) kumpulan informasi baru, (2) hasil objektif dari suatu kajian ilmu keolahragaan, dan (3) rekomendasi.

2. Penulisan naskah menggunakan bahasa Indonesia secara benar. Panjang naskah antara 7-20 halaman, kertas ukuran quarto, diketik 1,5 spasi, tipe huruf Times New Roman, ukuran huruf 12, margin atas dan kiri 4 cm, kanan dan bawah $3 \mathrm{~cm}$.

3. Naskah ditulis dengan sistematika dan ketentuan sebagai berikut.

a. Judul: ditulis dengan singkat, padat, terdiri dari 5-15 kata, dan menggunakan bahasa Indonesia, harus mencerminkan substansi keilmuan yang diuraikan pada batang tubuh artikel. Judul utama (main title) dan anak judul (subtitle) dipisahkan dengan dua titik. Judul artikel dicetak 15 mm dibawah tepi atas, dengan huruf capital-kecil tebal. Judul subbab peringkat 1 dicetak capital semua, rata tepi kiri, tebal, peringkat 2 dicetak capital kecil, rata tepi kiri, tebal; peringkat 3 dicetak kapital-kecil, rata tepi kiri, miring-tebal.

b. Nama penulis: Nama penulis artikel ditulis tanpa disertai gelar akademik atau gelar apapun. Nama lengkap dengan gelar akademik boleh ditulis disebelah bawah halaman pertama artikel. Nama lembaga tempat bekerja penulis juga dibuat sebagai catatan kaki dihalaman pertama. Jika lebih dari tiga penulis, hanya penulis utama saja yang dicantumkan dibawah judul; nama penulis lain ditulis dalam catatan kaki.

c. Abstrak artikel kajian ilmiah/ konseptual adalah ringkasan dari isi artikel yang dituangkan secara padat menggunakan bahasa Indonesia dan bahasa inggris. Abstrak hasil penelitian memuat masalah atau tujuan, metode, dan hasil penelitian. Abstrak terdiri dari 100-300 kata yang disusun dalam satu 
paragraph dengan format esei bukan enumeratif, dan diketik dengan spasi tunggal serta dengan format yang lebih sempit dari teks utama.

d. Kata Kunci terdiri dari 3-5 kata, yaitu istilah-istilah yang mewakili ide atau konsep dasar yang dibahas dalam penulisan karya ilmiah. Kata kunci lazimnya berupa kata dasar atau kata yang berdiri sendiri (tunggal) bukan rangkaian kata.

e. Naskah hasil penulisan ditulis dengan urutan (1) judul, (2) nama penulis, (3) abstrak, (4) kata kunci, (5) bagian pendahuluan yang harus di akhiri dengan rumusan singkat (1-2 kalimat) tentang hal-hal pokok yang akan dibahas dan tujuan dari pembahasan. Untuk artikel hasil penelitian berisi (a) rumusan masalah, (b) tujuan, dan (c) deskripsi singkat mengenai kerangka pemikiran dalam pendahuluan, (6) isi memuat (a) metode penelitian, (b) hasil penelitian, dan (c) pembahasan. (8) simpulan dan saran, (9) daftar pustaka.

f. Naskah diluar hasil penelitian ditulis dengan urutan (1) judul, (2) nama penulis, (3) abstrak, (4) kata kunci, (5) pendahuluan yang memuat latar belakang dan rumusan masalah, (6) isi, (7) simpulan, dan (8) daftar pustaka.

g. Table dan gambar/ bagan di usahakan dicetak dalam satu halaman, nomor dan judul table dan gambar dicetak di atas table dengan huruf tebal. Isi dalam table dicetak dengan huruf normal (tidak tebal). Table hanya menggunakan garis horizontal (horizontal border)

h. Penulisan daftar pustaka

1) Buku ditulis dengan urutan: (a) nama akhir, (b) koma, (c) nama depan penulis, (d) titik, (e) tahun penerbitan, (f) titik, (g) judul buku dalam huruf miring, (h) titik, (i) edisi jika ada, (j) titik, (k) kota penerbitan, (l) titik dua, (m) nama penerbit, dan (n) titik.

2) Artikel ditulis dengan urutan: (a) nama akhir, (b) koma, (c) nama depan penulis, (d) titik, (e) tahun penerbitan, (f) titik, (g) tanda petik dua, (h) judul artikel, (i) titik, (j) tanda petik tutup, (k) nama jurnal dalam cetak miring, (l) volume, (m) nomor, dan (n) titik. Apabila artikel diterbitkan 
disuatu buku, tulis kata "dalam" sebelum nama editor buku tersebut, dan buku harus ditulis didalam daftar pustaka.

3) Skripsi, thesis, atau disertasi ditulis dengan urutan: (a) nama akhir, (b) koma, (c) nama depan penulis, (d) titik, (e) tahun, (f) titik, (g) judul dalam huruf miring, (h) skripsi/thesis/disertasi pada (nama perguruan tinggi yang bersangkutan), (i) nama kota, (j) titik dua, (k) tulisan "tidak diterbitkan", dan (1) titik. 